\title{
Prognostic Significance of Absolute Lymphocytic Count Recovery in Pediatric Patients with Acute Lymphoblastic Leukemia at South Egypt Cancer Institute
}

\author{
Azza Shibl1, Noha Gaber², Nelly Alieldin³ ${ }^{3}$ Heba Sayed ${ }^{*}$ \\ ${ }^{1}$ Department of Pediatric Oncology, South Egypt Cancer Institute (SECI), Assiut University, Assiut, Egypt \\ ${ }^{2}$ Department of Clinical Pathology, South Egypt Cancer Institute (SECI), Assiut University, Assiut, Egypt \\ ${ }^{3}$ Department of Cancer Epidemiology, National Cancer Institute, Cairo, Egypt \\ Email: *hebadina2007@yahoo.com
}

How to cite this paper: Shibl, A., Gaber, N., Alieldin, N. and Sayed, H. (2019) Prognostic Significance of Absolute Lymphocytic Count Recovery in Pediatric Patients with Acute Lymphoblastic Leukemia at South Egypt Cancer Institute. Journal of Cancer Therapy, 10, 958-970.

https://doi.org/10.4236/jct.2019.1012082

Received: November 16, 2019

Accepted: December 17, 2019

Published: December 20, 2019

Copyright ( $\odot 2019$ by author(s) and Scientific Research Publishing Inc. This work is licensed under the Creative Commons Attribution International License (CC BY 4.0).

http://creativecommons.org/licenses/by/4.0/

\begin{abstract}
Background: Leukemia is the most common cause of disease-related death in childhood despite significant improvement in survival and modern risk stratification. Prognostic significance of absolute lymphocytic count (ALC) recovery was studied in pediatric patients with acute lymphoblastic leukemia (ALL). Methods: One hundred twenty one patients newly diagnosed as ALL $\leq 18$ yearstreated at pediatric oncology department, South Egypt Cancer Institute from 2011 to 2015 were enrolled. Age, sex, initial total leucocytic count, immunophenotyping, central nervous system (CNS) involvement, mediastinal mass, bone marrow (BM) response on day fifteen and after finishing induction remission were compared to ALC recovery on day 15 (ALC-15) and day 29 (ALC-29) of induction response. Also, prognostic impact of ALC recovery on event free survival (EFS) and overall survival (OS) was evaluated. Results: ALC didn't show any significant relation to known patients' prognostic factors. Patients with low ALC didn't show significant lower response on day 15 and post induction evaluation from those with high ALC ( $\mathrm{p}=0.74,0.6$ respectively). ALC- $15 \geq 500$ cells/uL showed a prognostic significance as patients with ALC- $15<500$ cells/uL had a poorer outcome (4EFS $47.8 \% \pm 0.12 \%)$ than patients with ALC- $15 \geq 500$ cells/uL who carried a better outcome (4-EFS $66.3 \% \pm 0.05 \%$ ). Neither ALC-500 (day 29) nor ALC-350 (day 15 \& day 29) had impact on OS or EFS. In multivariate analysis, ALC- $15<500$ cells/uL still had a poor impact on outcome (OR 2.56, 95\% CI 1.27 - 5.14) with d15-BM response (OR 2.99, 95\% CI 1.35 - 6.61) and age < 10 (OR 1.96, 95\% CI 1.01 - 3.69). Conclusions: ALC-15 has an independent
\end{abstract}


prognostic impact on outcome as well as simple, inexpensive, and easy to interpret. Although, it's utility in risk stratification of ALL still need a confirmation through a multicenter study with uniform variables, large cohort and long duration of follow up.

\section{Keywords}

ALC, Pediatric ALL, Outcome

\section{Introduction}

Acute lymphoblastic leukemia (ALL) in childhood is the most common hematological malignancy. Improvement of the outcomes for the disease have significantly observed in last decades, mainly due to introduction of better risk stratification therapeutic strategies and due to use of superior salvage regimes and better supportive care [1] [2].

The outcome of pediatric ALL in most of the current treatment protocols can be predicted by many proven factors: initial white blood cell count (WBC), age, immunophenotype (B- or T-ALL), cytogenetics $(t(9 ; 22)$ or $t(4 ; 11))$ and response to treatment [3] [4] [5]. The most reliable independent predictor of survival and relapse in pediatric ALL is the minimal residual disease (MRD) identified by flow cytometry or molecular genetic technique [3] [4]. However, in most developing countries, the complexity, cost, and training required in performing and interpreting MRD precludes its use. Hence, there is a need to devise a simpler and widely applicable methods to accurately risk stratify patients [2].

Absolute Lymphocytic Count (ALC) was found to be prognostic of overall survival and event-free survival (EFS) in multiple studies [2] [6]-[13]. Higher ALC measured during induction chemotherapy was associated with superior survival in both adult and pediatric ALL [14]. This observation was based on the knowledge that lymphocytes constitute an effective natural mechanism of the immune system against tumor cells. So, that early lymphocyte recovery is associated with better outcome [15] [16].

However, ALC measurement time point and cut-off value were not universally determined in all the previous studies as various measurement time points (day 13, day 28, day 29, day 36 and day 43) and ALC cut-off values (350 cells, 500 cells, 900 cells, 1000 cells and 1500 cells) were found to be predictive of outcome [6]-[13]. In patients treated with the Total Therapy XV study at St. Jude Children's Research Hospital, ALC $\geq 500$ cell/ $\mu \mathrm{L}$ at the end of induction remission was significantly related to favorable presenting feature and associated with OS in the univariate analysis only [10]. We use the earlier Total Therapy TXIII-B study with the same treatment regimen in the first 15 days of induction remission with a shorter duration of induction remission [10].

The purpose of our study was to determine the prognostic impact of ALC re- 
covery on the survival rates at different time points and different cutoff points during induction remission of patients treated with Total Therapy study TXIII-B adopted from St. Jude Children's Research Hospital, and the possibility of its using as an independent factor especially in a scenario where MRD estimation is not feasible.

\section{Patients and Methods}

This retrospective study included 121 newly diagnosed pediatric ALL patients ( $\leq 18$ years) admitted at pediatric oncology department, South Egypt Cancer Institute from June 2011 to December 2015 after approval by institutional ethical committee. Children who received steroid or chemotherapy before enrollment in the study were excluded. Also, patients who died early within one week of admission were excluded (before time of evaluation).

The patients were treated according to modified Total Therapy study XIIIB adopted from St. Jude Children's Research hospital (SJCRH). Data collected from patients' records included demographic and clinical data (age, sex, CNS involvement, total leucocyte count (TLC), and immunophenotyping). Also, early response, induction of remission response and outcome of the patients were reported.

Absolute lymphocytic count (ALC) as indicator of immune recovery was obtained from patients' records on day 15 (ALC-15) and on day 29 (ALC-29) of induction. We studied its relation to the previous collected patients' charateristics at initial diagnosis and to the induction of remission response. Then we evaluated its prognostic impact on patients outcome (event free survival (EFS) and overall survival (OS)) at two different cut off levels (ALC $<500$ or $\geq 500$ cells $/ \mathrm{ml}$ and ALC $<350$ or $\geq 350$ cells $/ \mathrm{ml}$ ).

\section{Statistical Analysis}

SPSS version 23.0 was used for data management. Numerical data were described with median and range and categorical with number and percentage. ALC values were analyzed separately at two different cut-off points $(<350$ cells $/ \mu \mathrm{l}$ vs. $\geq 350$ and $<500$ cells $/ \mu \mathrm{l}$ vs $\geq 500$ cells $/ \mu \mathrm{l}$ ) on both day 15 and day 29 of induction remission. Chi-square/Fisher exact tests were used for testing proportion independence. The duration of EFS was measured from the date of complete remission to the date of the first treatment failure of any kind (relapse, death, lineage switch, or second malignancy) or to the date of the most recent follow-up. The duration of OS was calculated from the date of enrollment to the date of death due to any cause or the date of the most recent follow-up. Kaplan-Meier method was used to estimate both OS and EFS, and comparisons between groups were made using the log-rank test. To find independent prognostic factors that impact EFS, cox regression analysis was used and it included variables that were significant on univariate analysis. $\mathrm{P}$ value was always two tailed and significant at 0.05 level. 


\section{Results}

\subsection{Patients' Characteristics}

The median age of the 121 newly diagnosed pediatric ALL patients included in this study was 5 years with male to female ratio of 1.4: 1. Favorable prognostic factors (age $<10$ years, initial TLC $<50 \&$ precursor B-ALL phenotype) at time of diagnosis were more prominent among the study group $(72.7 \%, 68.59 \% \&$ $78.5 \%$ respectively). Seven patients (5.79\%) presented with CNS manifestations at diagnosis and mediastinal mass was reported in $12.6 \%$ of patients. Rapid early response on day 15 of remission induction phase was achieved in $87.6 \%$ and complete post induction remission was reported in $86 \%$. Our patients had a 4 -year OS of $75.2 \% \pm 0.05 \%$ and 4 -year EFS of $62.8 \% \pm 0.04 \%$. Table 1 shows characteristics of patients included in the study.

Table 1. Patients' characteristics (121 patients).

\begin{tabular}{|c|c|c|}
\hline \multicolumn{2}{|c|}{ Patients' characteristics } & \multirow{2}{*}{$\frac{\mathrm{N}(\%)}{5(1-16) \text { years }}$} \\
\hline Age & Median (range) & \\
\hline & $<10$ years & $88(72.73)$ \\
\hline & $\geq 10$ years & $33(27.27)$ \\
\hline \multirow[t]{3}{*}{ Sex } & Male & $70(57.85)$ \\
\hline & Female & $51(42.15)$ \\
\hline & $\mathrm{M} / \mathrm{F}$ ratio & $1.4 / 1$ \\
\hline \multirow[t]{3}{*}{ Initial TLC } & Median (range) & $17.2(0.9-576)$ \\
\hline & $<50,000$ & $83(68.59)$ \\
\hline & $\geq 50,000$ & $38(31.41)$ \\
\hline \multicolumn{3}{|l|}{ ALC } \\
\hline ALC-15 - 350 & $<350$ vs $\geq 350$ cells $/ \mu \mathrm{l}$ & 10 vs 111 \\
\hline ALC-15 - 500 & $<500$ vs $\geq 500$ cells $/ \mu \mathrm{l}$ & 23 vs 98 \\
\hline ALC-29 - 350 & $<350$ vs $\geq 350$ cells/ $\mu \mathrm{l}$ & 3 vs 118 \\
\hline ALC-29 - 500 & $<500$ vs $\geq 500$ cells $/ \mu \mathrm{l}$ & 7 vs 114 \\
\hline \multirow[t]{2}{*}{ Mediastinal mass ${ }^{*}$} & Present & $15(12.60)$ \\
\hline & Absent & $104(87.40)$ \\
\hline \multirow[t]{2}{*}{ Immunophenotyping } & B-ALL & $95(78.51)$ \\
\hline & T-ALL & $26(21.49)$ \\
\hline \multirow[t]{2}{*}{ CNS involvement } & Yes & $7(5.79)$ \\
\hline & No & $114(94.21)$ \\
\hline \multirow[t]{2}{*}{ Early response } & RER & $106(87.60)$ \\
\hline & SER & $15(12.40)$ \\
\hline \multirow[t]{2}{*}{ Induction response } & $\mathrm{CR}$ & $104(86)$ \\
\hline & Not & $17(14)$ \\
\hline \multicolumn{2}{|l|}{4 year overall survival } & $75.2 \% \pm 0.05 \%$ \\
\hline \multicolumn{2}{|c|}{4 year event free survival } & $62.8 \% \pm 0.04 \%$ \\
\hline
\end{tabular}

TLC: total leukocytic count; ALC: absolute lymphocytic count; CNS: central nervous system; RER: rapid early response; SER: slow early response; CR: complete remission. ${ }^{*}$ data were available for 119 patients only. 


\subsection{Absolute Lymphocytic Count (ALC)}

To exclude the possible effect of bone marrow infiltration at time of diagnosis, we studied the ALC on days 15 and 29 and evaluated their impact as a prognostic factor in ALL at two different cut off levels ALC 350 ( $<$ or $\geq 350$ cell $/ \mu \mathrm{l})$ and ALC $500(<$ or $\geq 500$ cell $/ \mu \mathrm{l})$.

Among the study group, the median level of ALC on day 15 (ALC-15) was 1000 ranged from $100-11,000$ cells/ $\mu \mathrm{l}$ and the median level of ALC on day 29 of induction (ALC-29) was 1300 and ranged from $40-8400$ cells/ $\mu$. The majority of patients on day 15 and on day 29 of induction had ALC $\geq 350$ (91.7\% \& 97.5\% respectively). Similarly, most of the patients on day 15 and on day 29 of induction had ALC $\geq 500$ ( $80 \% \& 94.2 \%$ respectively) (Table 1 ).

\subsection{ALC and Other Prognostic Factors}

We notice that, the ALC levels of $\geq 350 \mathrm{cell} / \mu \mathrm{l}$ and $\geq 500 \mathrm{cell} / \mu \mathrm{l}$ were associated with criteria of favorable prognosis (age $<10$ years, TLC $<50,000$, B phenotype, absence of CNS infiltration and rapid early response) both on days 15 and 29 as shown in Table 2 and Table 3 . This notice hadn't confirmed by any significant value in statistical analysis. Again, CR response post induction was more prominent in patients with ALC $\geq 350 \mathrm{cell} / \mu \mathrm{l}$ and $\geq 500 \mathrm{cell} / \mu \mathrm{l}(86.5 \%$ and $85.7 \% \mathrm{re}$ spectively) on day 15 and ( $85.6 \%$ and $85 \%$ respectively) on day 29 with no statistical significance (Table $2 \&$ Table 3 ).

Table 2. Relation between (ALC-15) and other patients' characteristics.

\begin{tabular}{|c|c|c|c|c|c|c|c|c|}
\hline \multicolumn{2}{|c|}{ Patients' characteristics } & $\begin{array}{c}\text { Total } \\
(\mathrm{n} .=121)\end{array}$ & $\begin{array}{c}<500 \\
(n .=23)\end{array}$ & $\begin{array}{c}\geq 500 \\
(\mathrm{n} .=98)\end{array}$ & p-Value & $\begin{array}{c}<350 \\
(\mathrm{n} .=10)\end{array}$ & $\begin{array}{c}\geq 350 \\
\text { (n. }=111)\end{array}$ & p-Value \\
\hline \multirow[t]{2}{*}{ Age: } & $<10$ years & 88 & $19(21.60 \%)$ & $69(78.40 \%)$ & & $8(9.10 \%)$ & $80(90.90 \%)$ & \\
\hline & $\geq 10$ years & 33 & $4(12.12 \%)$ & $29(87.88 \%)$ & 0.24 & $2(6.06 \%)$ & $31(93.94 \%)$ & 0.73 \\
\hline \multirow[t]{2}{*}{ Sex } & Male & 70 & $15(21.43 \%)$ & $55(78.57 \%)$ & & $6(8.37 \%)$ & $64(91.43 \%)$ & \\
\hline & Female & 51 & $8(15.69 \%)$ & $43(84.31 \%)$ & 0.43 & $4(7.84 \%)$ & $47(92.16 \%)$ & 1.0 \\
\hline \multirow[t]{2}{*}{ TLC } & $<50,000$ cells $/ \mu \mathrm{l}$ & 83 & $18(21.69 \%)$ & $65(78.31 \%)$ & & $8(9.64 \%)$ & $75(90.36 \%)$ & \\
\hline & $\geq 50,000$ cells $/ \mu \mathrm{l}$ & 38 & $5(13.16 \%)$ & $33(86.84 \%)$ & 0.33 & $2(5.26 \%)$ & $36(94.74 \%)$ & 0.50 \\
\hline \multicolumn{9}{|c|}{ Mediastinal mass (119)* } \\
\hline \multicolumn{2}{|c|}{ Present } & 15 & $3(20 \%)$ & $12(80 \%)$ & \multirow{2}{*}{1.0} & 0 & $15(100 \%)$ & \multirow{2}{*}{0.36} \\
\hline & bsent & 104 & $19(18.27 \%)$ & $85(81.73 \%)$ & & $10(9.62 \%)$ & $94(90.38 \%)$ & \\
\hline \multicolumn{9}{|c|}{ Immunophenotyping } \\
\hline & -ALL & 95 & $21(22.11 \%)$ & $74(78.89 \%)$ & \multirow{2}{*}{0.16} & $9(9.5 \%)$ & $86(90.5 \%)$ & \multirow{2}{*}{0.69} \\
\hline & -ALL & 26 & $2(7.70 \%)$ & $24(92.30 \%)$ & & $1(3.85 \%)$ & $25(96.15 \%)$ & \\
\hline \multicolumn{9}{|c|}{ CNS involvement } \\
\hline & Yes & 7 & $1(14.29 \%)$ & $6(85.71 \%)$ & \multirow{2}{*}{1.0} & $1(14.29 \%)$ & $6(85.71 \%)$ & \multirow{2}{*}{0.46} \\
\hline & No & 114 & $22(19.30 \%)$ & $92(80.70 \%)$ & & $9(7.89 \%)$ & $105(92.11 \%)$ & \\
\hline \multicolumn{9}{|c|}{ Early response } \\
\hline & RER & 106 & $21(19.81 \%)$ & $85(80.19 \%)$ & \multirow{2}{*}{0.74} & $8(7.55 \%)$ & $98(92.45 \%)$ & \multirow{2}{*}{0.36} \\
\hline & SER & 15 & $2(13.33 \%)$ & $13(86.67 \%)$ & & $2(13.33 \%)$ & $13(86.67 \%)$ & \\
\hline \multicolumn{9}{|c|}{ Induction response } \\
\hline & CR & 104 & $20(19.33 \%)$ & $84(80.77 \%)$ & \multirow{2}{*}{1.0} & $8(7.70 \%)$ & $96(92.30 \%)$ & \multirow{2}{*}{0.63} \\
\hline & not & 17 & $3(17.65 \%)$ & $14(82.35 \%)$ & & $2(11.76 \%)$ & $15(88.24 \%)$ & \\
\hline
\end{tabular}

TLC: total leukocytic count; ALC: absolute lymphocytic count; CNS: central nervous system; RER: rapid early response; SER: slow early response; CR: complete remission. ${ }^{*}$ data were available for 119 patients only. 
Table 3. Relation between (ALC-29) and Patients' characteristics.

\begin{tabular}{|c|c|c|c|c|c|c|c|c|}
\hline \multicolumn{2}{|c|}{ Patients' characteristics } & $\begin{array}{c}\text { Total } \\
(\mathrm{n}=121)\end{array}$ & $\begin{array}{c}<500 \text { cells } / \mu \mathrm{l} \\
\quad(\mathrm{n}=7)\end{array}$ & $\begin{array}{c}\geq 500 \text { cells } / \mu \mathrm{l} \\
\quad(\mathrm{n}=114)\end{array}$ & p-value & $\begin{array}{c}<350 \text { cells } / \mu \mathrm{l} \\
(\mathrm{n}=3)\end{array}$ & $\begin{array}{c}\geq 350 \text { cells } / \mu \mathrm{l} \\
\quad(\mathrm{n}=118)\end{array}$ & p-value \\
\hline \multicolumn{9}{|l|}{ Age } \\
\hline & $<10$ & 88 & $5(5.68 \%)$ & $83(94.32 \%)$ & \multirow{2}{*}{1.0} & $3(3.44 \%)$ & $85(96.56 \%)$ & \multirow{2}{*}{0.56} \\
\hline & $\geq 10$ & 33 & $2(6.06 \%)$ & $31(93.94 \%)$ & & $0(0 \%)$ & $33(100 \%)$ & \\
\hline \multirow[t]{2}{*}{ Sex } & Male & 70 & $4(5.71 \%)$ & $66(94.29 \%)$ & \multirow[b]{2}{*}{1.0} & $2(2.86 \%)$ & $68(97.14 \%)$ & \multirow[b]{2}{*}{1.0} \\
\hline & female & 51 & $3(5.88 \%)$ & $48(94.12 \%)$ & & $1(2 \%)$ & $50(98 \%)$ & \\
\hline \multirow[t]{2}{*}{ TLC } & $<50,000$ cells $/ \mu \mathrm{l}$ & 83 & $3(3.62 \%)$ & $80(96.38 \%)$ & \multirow[b]{2}{*}{0.20} & $2(2.41 \%)$ & $81(97.59 \%)$ & \multirow[b]{2}{*}{1.0} \\
\hline & $\geq 50,000$ cells $/ \mu \mathrm{l}$ & 38 & $4(10.53 \%)$ & $34(89.47 \%)$ & & $1(2.63 \%)$ & 37 (97.37\%) & \\
\hline \multicolumn{9}{|c|}{ Mediastinal mass (119)* } \\
\hline & Present & 15 & $1(6.67 \%)$ & $14(93.33 \%)$ & \multirow{2}{*}{1.0} & 0 & $15(100 \%)$ & \multirow{2}{*}{1.0} \\
\hline & absent & 104 & $6(5.77 \%)$ & $98(94.23 \%)$ & & $3(2.88 \%)$ & $101(97.12 \%)$ & \\
\hline \multicolumn{9}{|c|}{ Immunophenotyping } \\
\hline & B-ALL & 95 & $5(5.26 \%)$ & $90(94.74 \%)$ & \multirow{2}{*}{0.64} & $2(2.11 \%)$ & $93(97.89 \%)$ & \multirow{2}{*}{0.52} \\
\hline & T-ALL & 26 & $2(7.69 \%)$ & $24(92.31 \%)$ & & $1(3.85 \%)$ & $25(96.15 \%)$ & \\
\hline \multicolumn{9}{|c|}{ CNS involvement } \\
\hline & Yes & 7 & 0 & $7(100 \%)$ & \multirow{2}{*}{1.0} & 0 & $7(100 \%)$ & \multirow{2}{*}{1.0} \\
\hline & no & 114 & $7(6.14 \%)$ & $107(93.86 \%)$ & & $3(2.63 \%)$ & $111(97.37 \%)$ & \\
\hline \multicolumn{9}{|c|}{ Early response } \\
\hline & RER & 106 & $7(6.60 \%)$ & 99 (93.40\%) & \multirow{2}{*}{0.60} & $3(2.83 \%)$ & $103(97.17 \%)$ & \multirow{2}{*}{1.0} \\
\hline & SER & 15 & 0 & $15(100 \%)$ & & 0 & $15(100 \%)$ & \\
\hline \multicolumn{9}{|c|}{ Induction response } \\
\hline & CR & 104 & $7(6.73 \%)$ & 97 (93.27\%) & \multirow{2}{*}{0.59} & $3(2.88 \%)$ & $101(97.12 \%)$ & \multirow{2}{*}{1.0} \\
\hline & not & 17 & 0 & $17(100 \%)$ & & 0 & $17(100 \%)$ & \\
\hline
\end{tabular}

TLC: total leukocytic count; ALC: absolute lymphocytic count; CNS: central nervous system; RER: rapid early response; SER: slow early response; CR: complete remission. ${ }^{*}$ data were available for 119 patients only.

\subsection{ALC and Outcome}

In univariate analysis, ALC- $15 \geq 500$ cell/ $\mu$ l was significantly associated with a superior EFS; 4-year EFS for patients with ALC-15 $\geq 500 \mathrm{cell} / \mu \mathrm{l}$ was $66.3 \% \pm$ $0.05 \%$ versus 4 year EFS of $47.8 \% \pm 0.10 \%$ for patients with ALC- $15<500$ cell $/ \mu \mathrm{l}$ $(\mathrm{p}=0.040)$ (Figure 1). Neither ALC-500 (day 29) nor ALC-350 (day 15 \& day 29) had impact on OS or EFS (Table 4).

When studying the known prognostic factors affecting the outcome of patients in our study as age, immunophenotyping, initial TLC and early response, we confirmed age $<10$ years and rapid early response as predictors of good prognosis, patients with age $<10$ years had EFS of $65.9 \% \pm 0.05 \%$ versus $54.4 \% \pm$ $0.09 \%$ in patients $\geq 10$ years $(\mathbf{P}=\mathbf{0 . 0 5 0})$, patients with rapid early response had 4 -year EFS of $65.1 \% \pm 0.05 \%$ while those with slow early response had 4year EFS of $46.7 \% \pm 0.13 \%$ ( $p=0.016)$. Immunophenotyping and initial TLC didn't show significant impact on EFS ( $\mathrm{p}=0.1 \& 0.56$ respectively) in this study (Table 5).

In multivariate analysis, ALC- $15<500 \mathrm{cell} / \mu \mathrm{l}$ was still have a highly significant inferior impact on EFS $(P=0.009)$ together with age $\geq 10$ year $(p=0.037)$ and patients with SER $(\mathrm{p}=0.007)$ (Table 6). 


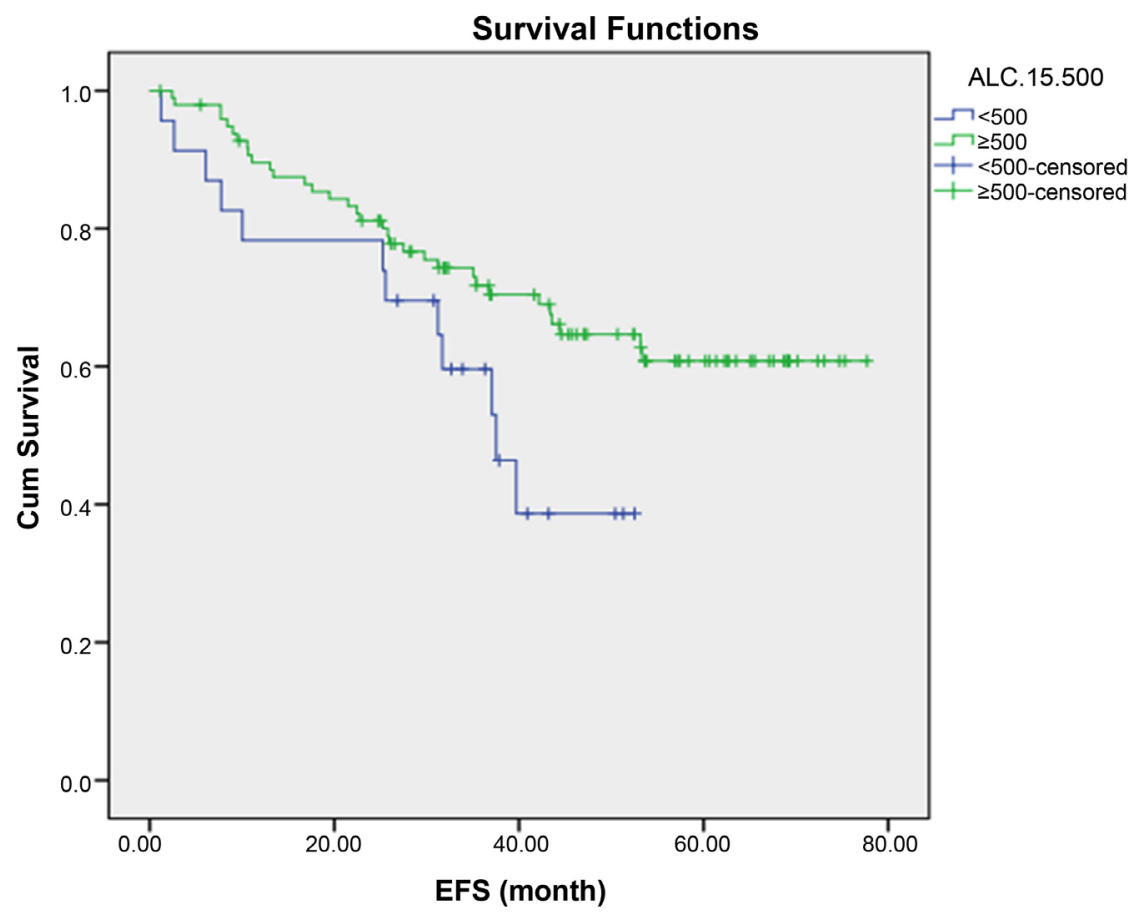

Figure 1. 4-year EFS for patients with ALC-15 $\geq 500 \mathrm{cell} / \mu \mathrm{l}$ was $66.3 \% \pm 0.05 \%$ versus 4 year EFS of $47.8 \% \pm 0.1 \%$ for patients with ALC- $15<500 \mathrm{cell} / \mu \mathrm{l}(\mathrm{p}=0.04)$.

Table 4. Four-year overall survival and event free survival of 121 pediatric all patients in regard to ALC.

\begin{tabular}{|c|c|c|c|c|}
\hline & $4-Y e a r$ OS \pm SE & p-Value & 4 -Year EFS $\pm \mathrm{SE}$ & p-Value \\
\hline \multicolumn{5}{|l|}{ ALC-15 } \\
\hline$<350$ cells $/ \mu \mathrm{l}$ & $70 \% \pm 0.16 \%$ & \multirow{2}{*}{0.328} & $50 \% \pm 0.15 \%$ & \multirow[t]{2}{*}{0.135} \\
\hline$\geq 350$ cells $/ \mu \mathrm{l}$ & $75.7 \% \pm 0.04 \%$ & & $64 \% \pm 0.05 \%$ & \\
\hline \multicolumn{5}{|l|}{ ALC-29 } \\
\hline$<350$ cells $/ \mu \mathrm{l}$ & $66.7 \% \pm 0.27 \%$ & 0.856 & $66.7 \% \pm 0.27 \%$ & 0.795 \\
\hline$\geq 350 \mathrm{cells} / \mu \mathrm{l}$ & $75.4 \% \pm 0.04 \%$ & & $62.7 \% \pm 0.05 \%$ & \\
\hline \multicolumn{5}{|l|}{ ALC-15 } \\
\hline$<500$ cells $/ \mu \mathrm{l}$ & $78.3 \% \pm 0.09 \%$ & 0.946 & $47.8 \% \pm 0.10 \%$ & 0.040 \\
\hline$\geq 500$ cells $/ \mu \mathrm{l}$ & $74.5 \% \pm 0.04 \%$ & & $66.3 \% \pm 0.05 \%$ & \\
\hline \multicolumn{5}{|l|}{ ALC-29 } \\
\hline$<500$ cells $/ \mu \mathrm{l}$ & $57 \% \pm 0.19 \%$ & 0.278 & $57 \% \pm 0.19 \%$ & 0.790 \\
\hline$\geq 500$ cells $/ \mu \mathrm{l}$ & $76.3 \% \pm 0.04 \%$ & & $63.2 \% \pm 0.05 \%$ & \\
\hline
\end{tabular}

EFS: event free survival; OS: overall survival; ALC: absolute lymphocytic count.

Table 5. Prognostic factors affecting 4-year EFS.

\begin{tabular}{llcc}
\hline & & 4-Year EFS & p-Value \\
\hline \multirow{2}{*}{ Age } & $<10$ years & $65.9 \% \pm 0.05 \%$ & \\
& $\geq 10$ years & $54.5 \% \pm 0.09 \%$ & 0.070 \\
TLC & $<50,000$ cells/ $\mu \mathrm{l}$ & $63.9 \% \pm 0.06 \%$ & 0.592 \\
& $\geq 50,000$ cells/ $\mu \mathrm{l}$ & $60.5 \% \pm 0.08 \%$ & \\
Immunophenotyping & & 0.112 \\
& B-ALL & $66.3 \% \pm 0.05 \%$ & \\
& T-ALL & $50 \% \pm 0.10 \%$ &
\end{tabular}


Continued

Early response

RER

$65.1 \% \pm 0.05 \%$

SER

$46.7 \% \pm 0.13 \%$

0.016

EFS; event free survival, OS; overall survival, TLC; total leukocytic count, ALC; absolute lymphocytic count, CNS; central nervous system, RER; rapid early response, SER; slow early response.

Table 6. Multivariate analysis Cox regression analysis of event free survival of 121 all pediatric patients.

\begin{tabular}{ccccccc}
\hline & & & & & \multicolumn{2}{c}{$95.0 \%$ CI for OR } \\
\cline { 6 - 7 } & B & SE & p Value & OR & Lower & Upper \\
\hline Age $(\geq 10$ years $)$ & 0.672 & 0.323 & 0.037 & 1.959 & 1.040 & 3.688 \\
ALC on day $15<500$ & 0.938 & 0.357 & 0.009 & 2.555 & 1.270 & 5.141 \\
D15 response (SER) & 1.094 & 0.405 & 0.007 & 2.987 & 1.350 & 6.609 \\
\hline
\end{tabular}

$\mathrm{B}=$ regression coefficient, $\mathrm{SE}=$ standard error, $\mathrm{OR}=$ odds ratio, $\mathrm{CI}=$ confidence interval.

\section{Discussion}

Acute lymphoblastic leukemia is the most common malignancy of childhood with cure rates approaching $80 \%$ with modern therapy [17]. Better risk stratification strategies, based on specific patients related and leukemic cell factors, and improvement in supportive care accounted for these results [18].

In this study, we retrospectively assessed the predictive role of absolute lymphocytic recovery at two settings (day 15 and day 29) of induction remission phase on the outcome of a cohort of 121 patients with ALL treated at South Egypt Cancer institute in a developing country with limited resources.

The median WBC at diagnosis was $17.2 \times 10^{3} \mathrm{cell} / \mathrm{ul}$ which considered high when compared to $9.22 \times 10^{3}$ cells/ul reported by Farkas et al. [1] and 12.260 cell/ul by Hatzipantelis et al. [12] which may be explained by a higher incidence of $\mathrm{T}$ phenotype among our patients. This comes true when we found that the median initial WBC count of 4300 cell/ul reported by Rolf et al. [19] who studied ALC in a group of patients with B-ALL.

Different prognostic ALC cut-off values and measurement time points have been identified, most likely due to marked differences between patients' characteristics and therapy protocols [1] [2] [11]. To exclude the possible effect of bone marrow infiltration at time of diagnosis, we studied the ALC on days 15 and 29 and evaluated their impact as a prognostic factor in ALL at two different cut off levels ALC 350 ( $<$ or $\geq 350$ cell $/ \mu$ l) and ALC 500 ( $<$ or $\geq 500$ cell/ $/ \mu l)$. Although we notice that, the ALC levels of $\geq 350 \mathrm{cell} / \mu \mathrm{l}$ and $\geq 500 \mathrm{cell} / \mu \mathrm{l}$ were associated with criteria of favorable prognosis both on days 15 and 29, we did not report any significant association in statistical analysis. Farkas et al. [1] and Gupta et al. [2] reported that their patients with low ALC values tend to have a higher risk (MR or HR groups) and a higher age at diagnosis ( $>10$ years) on day 15 of induction with similar cutoff ALC value. Rolf et al. [19] when investigated the relationship 
between D29 ALC and age as continuous variables also reported a significant inverse correlation $(r=-0.47 ; \mathrm{p}=0.033)$. A finding that confirms the general observation that lymphocyte counts decrease with increasing age [20]. Otherwise, they reported no significant difference in the median D29 ALC when their patients were grouped by risk status $(\mathrm{p}=0.95)$ or by MRD status $(\mathrm{p}=0.65)$; also gender.

Several previous studies have also examined this prognostic factor in childhood ALL, with varying results. They have used different ALC cut-offs and at different time points. The ALC cut-offs were different that may be accounted for differences in chemotherapy protocol as well as demographic and disease-related characteristics. So, we tried to reach the precise prognostic cutoff point and time to be used in further prospective studies in our center in the absence of MRD assessment to refine our patients as we found that among our patients with favorable criteria, who behaved a bad outcome.

When we retrospectively assessed the impact of absolute lymphocyte recovery during induction to predict treatment outcome in our patients cohort, the results of our study revealed that ALC recovery on day 15 of induction was demonstrated to be an independent predictor of survival [ALC- $15<500 \mathrm{cell} / \mu \mathrm{l}$ have a highly significant inferior impact on EFS $(P=0.009)]$ together with other established predictors of outcome such as age $\geq 10$ year $(\mathrm{p}=0.037)$ and patients with SER ( $p=0.007)$. The immunophenotyping and the initial TLC didn't show prognostic significance in this study that may due to a small size as 12 patients were lost follow up (abandoment). Also, there was a high rate of death and relapse among patients with favorable features which make the difference insignificant.

Similar to our results, Gupta et al. [2] from a developing country published their results on 212 patients using ALC cut off of 500 and 1000 cells/mL at D15 and D29, respectively, and found that they were significant predictors of EFS, relapse free survival (RFS), and OS that were still significant in multivariate analysis. We are similar to these results (ALC-15) and the majority of our patients had a higher ALC cutoff $(\geq 350, \geq 500)$ on day 15 and day $29(91.7 \%$ \& $97.5 \%$ respectively) ( $80 \% \& 94.2 \%$ respectively) [2], but we differed in that no significance of ALC-29 cutoff on survival that may be due to the different treatment protocol (4-drug versus our 6-drug regimen) and the different patients' characteristics as high risk features were more than in our study TLC $\geq$ $50,000 / \mathrm{ml}$ (36.8\% versus $31.4 \%$ ) in our study, also, this study had a larger percentage of older age $\geq 9$ years (30.7\% versus $27.2 \%)\}$. Also, we are similar to earlier study of De Angulo et al. [6] that demonstrated a poor survival of patients with ALC-15 < 350 cells/microL, with a 6-year RFS of 43\% (HR 4.5, P = 0.002), whereas patients with an ALC-15 > 350 cells/microL had excellent outcome, with a 6 -year OS of $87 \%(\mathrm{HR} 0.2, \mathrm{P}=0.018)$ which remained a strong predictor in multivariate analysis with known prognostic factors. The patients cohort in De Angulo et al. [6] study were up to 21 years so, they had a higher risk age group, and they treated patients with 3 - 4 drug regimen induction treatment. 
Contrary to our results, Farkas et al. [1] published their study on 132 patients treated on BFM-ALLIC 2002 protocol revealed that ALC had a prognostic significance at the end of induction phase only not earlier as ALC higher than 350 cells/ $\mu \mathrm{L}$ measured on the 33th day of induction was associated with better Overall- and Event-Free Survival. This also may be due to the different treatment protocol to us and to the more favorable patients' characteristics in their study than us (TLC $<50,000$ were ( $83 \%$ versus $68.6 \%$ ) in our study and pre B constituted (82\% versus $78.5 \%)$ in our study. Also, Hatzipantelis et al. [12] who treated their patients on BFM/ALLIC 2009 protocol and had similar favorable patients' characteristics as Farkas et al. [1] showed a favorable prognosis of patients with ALC $\geq 350$ cells $/ \mathrm{ml}$ with a 5 -year OS of $92.3 \%$ versus $69.2 \%$ for ALC $<350$ cells/ $\mathrm{ml}(\mathrm{HR} 2.2, \mathrm{P}=0.05)$.

Although, several studies including us reported ALC recovery as an independent prognostic factor in pediatric ALL, other studies [10] [21] failed to show independently significant prognostic value of ALC at end of induction in childhood leukemia. Also, among studies proved its significance, variables were not standardized and comparison is difficult.

Limitations in our study were being a retrospective study and the unavailability of MRD at that time.

\section{Conclusion}

Although our study proved the importance of ALC recovery as an independent prognostic factor in pediatric ALL in addition to consideration of ALC as a readily obtainable test, simple, inexpensive, and easy to interpret and MRD is not easily available all the time, we think its utility in risk stratification of ALL still needs a confirmation through a multicenter study with uniform variables, large cohort and long duration of follow up.

\section{Acknowledgements}

The authors received no financial or other support for the research reported in this manuscript.

\section{Conflicts of Interest}

The authors declare that they have no conflict of interests.

\section{References}

[1] Farkas, T., Müller, J., Erdelyi, D.J., Csoka, M. and Kovacs, G.T. (2017) Absolute Lymphocyte Count (ALC) after Induction Treatment Predicts Survival of Pediatric Patients with Acute Lymphoblastic Leukemia. Pathology \& Oncology Research, 23, 889-897. https://doi.org/10.1007/s12253-017-0192-8

[2] Gupta, A., Kapoor, G., Jain, S. and Bajpai, R. (2015) Absolute Lymphocyte Count Recovery Independently Predicts Outcome in Childhood Acute Lymphoblastic Leukemia: Experience from a Tertiary Care Cancer Center of a Developing Country. Journal of Pediatric Hematology/Oncology, 37, e143-e149. 
https://doi.org/10.1097/MPH.0000000000000249

[3] Basso, G., Veltroni, M., Valsecchi, M.G., Dworzak, M.N., Ratei, R., Silvestri, D., Benetello, A., Buldini, B., Maglia, O., Masera, G., Conter, V., Arico, M., Biondi, A. and Gaipa, G. (2009) Risk of Relapse of Childhood Acute Lymphoblastic Leukemia Is Predicted by Flow Cytometric Measurement of Residual Disease on Day 15 Bone Marrow. Journal of Clinical Oncology, 27, 5168-5174. https://doi.org/10.1200/JCO.2008.20.8934

[4] Gaipa, G., Cazzaniga, G., Valsecchi, M.G., Panzer-Grümayer, R., Buldini, B., Silvestri, D., Karawajew, L., Maglia, O., Ratei, R., Benetello, A., Sala, S., Schumich, A., Schrauder, A., Villa, T., Veltroni, M., Ludwig, W.D., Conter, V., Schrappe, M., Biondi, A., Dworzak, M.N. and Basso, G. (2012) Time Point-Dependent Concordance of Flow Cytometry and Real-Time Quantitative Polymerase Chain Reaction for Minimal Residual Disease Detection in Childhood Acute Lymphoblastic Leukemia. Haematologica, 97, 1582-1593. https://doi.org/10.3324/haematol.2011.060426

[5] Stary, J., Zimmermann, M., Campbell, M., Castillo, L., Dibar, E., Donska, S., Gonzalez, A., Izraeli, S., Janic, D., Jazbec, J., Konja, J., Kaiserova, E., Kowalczyk, J., Kovacs, G., Li, C.K., Magyarosy, E., Popa, A., Stark, B., Jabali, Y., Trka, J., Hrusak, O., Riehm, H., Masera, G. and Schrappe, M. (2014) Intensive Chemotherapy for Childhood Acute Lymphoblastic Leukemia: Results of the Randomized Intercontinental Trial ALL IC-BFM 2002. Journal of Clinical Oncology, 32, 174-184. https://doi.org/10.1200/JCO.2013.48.6522

[6] De Angulo, G., Yuen, C., Palla, S.L., Anderson, P.M. and Zweidler-McKay, P.A. (2008) Absolute Lymphocyte Count Is a Novel Prognostic Indicator in ALL and AML: Implications for Risk Stratification and Future Studies. Cancer, 112, 407-415. https://doi.org/10.1002/cncr.23168

[7] AnocetoMartínez, A., González Otero, A., Guerchicoff de Svarch, E., ArencibiaNuñez, A., Jaime, J.C., Dorticos, E., Sarduy, S. and González, L. (2012) Absolute Lymphocyte Count as a Prognostic Factor in Children with Acute Lymphoblastic Leukemia. Anales de Pediatría, 76, 10e1-10e6. https://doi.org/10.1016/j.anpedi.2011.07.001

[8] Rabin, K.R., Gramatges, M.M., Borowitz, M.J., Palla, S.L., Shi, X., Margolin, J.F. and Zweidler-McKay, P.A. (2012) Absolute Lymphocyte Counts Refine Minimal Residual Disease-Based Risk Stratification in Childhood Acute Lymphoblastic Leukemia. Pediatric Blood \& Cancer, 59, 468-474.

https://doi.org/10.1002/pbc.23395

[9] Sun, D., Elson, P., Liedtke, M., Medeiros, B.C., Earl, M., Alizadeh, A., Bates, J., Sekeres, M.A., Coutre, S., Kalaycio, M., Sobecks, R., Copelan, E. and Advani, A.S. (2012) Absolute Lymphocyte Count on day 28 Independently Predicts Event-Free and Overall Survival in Adults with Newly Diagnosed Acute Lymphoblastic Leukemia. American Journal of Hematology, 87, 957-960. https://doi.org/10.1002/ajh.23279

[10] Rubnitz, J.E., Campbell, P., Zhou, Y., Sandlund, J.T., Jeha, S., Ribeiro, R.C., Inaba, H., Bhojwani, D., Relling, M.V., Howard, S.C., Campana, D. and Pui, C.H. (2013) Prognostic Impact of Absolute Lymphocyte Counts at the End of Remission Induction in Childhood Acute Lymphoblastic Leukemia. Cancer, 119, 2061-2066. https://doi.org/10.1002/cncr.28026

[11] Shen, H.Q., Feng, J.H., Tang, Y.M., Song, H., Yang, S.L., Shi, S.W. and Xu, W.Q. (2013) Absolute Lymphocyte Count Is Associated with Minimal Residual Disease Level in Childhood B-Cell Precursor Acute Lymphoblastic Leukemia. Leukemia Research, 37, 671-674. https://doi.org/10.1016/j.leukres.2013.02.002 
[12] Hatzipantelis, E., Pana, Z.D., Vlachou, M., Papageorgiou, T., Tragiannidis, A. and Athanassiadou, F. (2014) Peripheral Blood Lymphocyte Recovery and Overall Survival in Pediatric Acute Lymphoblastic Leukemia. Pediatric Blood \& Cancer, 61, 181-183. https://doi.org/10.1002/pbc.24736

[13] Cheng, Y., Luo, Z., Yang, S., Jia, M., Zhao, H., Xu, W. and Tang, Y. (2015) The Ratio of Absolute Lymphocyte Count at Interim of Therapy to Absolute Lymphocyte Count at Diagnosis Predicts Survival in Childhood Blineage Acute Lymphoblastic Leukemia. Leukemia Research, 39, 144-150. https://doi.org/10.1016/j.leukres.2014.11.013

[14] Behl, D., Porrata, L.F., Markovic, S.N., Letendre, L., Pruthi, R.K., Hook, C.C., Tefferi, A., Elliot, M.A., Kaufmann, S.H., Mesa, R.A. and Litzow, M.R. (2006) Absolute Lymphocyte Count Recovery after Induction Chemotherapy Predicts Superior Survival in Acute Myelogenous Leukemia. Leukemia, 20, 29-34. https://doi.org/10.1038/sj.leu.2404032

[15] Benjamin, J.E., Gill, S. and Negrin, R.S. (2010) Biology and Clinical Effects of Natural Killer Cells in Allogeneic Transplantation. Current Opinion in Oncology, 22, 130-137. https://doi.org/10.1097/CCO.0b013e328335a559

[16] Norell, H., Moretta, A., Silva-Santos, B. and Moretta, L. (2013) At the Bench: Preclinical Rationale for Exploiting NK Cells and Gamma Delta T Lymphocytes for the Treatment of High-Risk Leukemias. Journal of Leukocyte Biology, 94, 1123-1139. https://doi.org/10.1189/jlb.0613312

[17] Pui, C.H., Campana, D., Pei, D., et al. (2009) Treating Childhood Acute Lymphoblastic Leukemia without Cranial Irradiation. The New England Journal of Medicine, 360, 2730-2741. https://doi.org/10.1056/NEJMoa0900386

[18] Smith, M., Arthur, D., Camitta, B., et al. (1996) Uniform Approach to Risk Classification and Treatment Assignment for Children with Acute Lymphoblastic Leukemia. Journal of Clinical Oncology, 14, 18-24. https://doi.org/10.1200/JCO.1996.14.1.18

[19] Rolf, N., Smolen, K.K., Kariminia, A., Velenosi, A., Fidanza, M., Strahlendorf, C., Seif, A.E. and Reid, G.S.D. (2018) Absolute Lymphocyte Counts at End of Induction Correlate with Distinct Immune Cell Compartments in Pediatric B Cell Precursor Acute Lymphoblastic Leukemia. Cancer Immunology, Immunotherapy, 67, 225-236. https://doi.org/10.1007/s00262-017-2070-3

[20] Tosato, F., Bucciol, G., Pantano, G., et al. (2015) Lymphocytes Subsets Reference Values in Childhood. Cytometry Part A, 87, 81-85. https://doi.org/10.1002/cyto.a.22520

[21] Alkayed, K., Halalsheh, H., Khattab, E., et al. (2012). Lack of Prognostic Significance of Absolute Lymphocyte Count after Intensive Induction Therapy in Childhood Acute Lymphoblastic Leukemia. Pediatric Blood \& Cancer, 59, 351. https://doi.org/10.1002/pbc.24120 


\section{Abbreviations}

\begin{tabular}{cc}
\hline ALC & Absolute lymphocytic count \\
ALL & Acute lymphoblastic leukemia \\
BM & Bone marrow \\
CNS & Central nervous system \\
EFS & Event free survival \\
OS & Overall survival \\
WBC & White blood cell count \\
MRD & Minimal residual disease \\
SJCRH & St. Jude Children's Research hospital \\
TLC & Total leucocyte count \\
RFS & Relapse free survival \\
RER & Rapid early response \\
SER & Slow early response \\
CR & Complete remission
\end{tabular}

